\title{
Selfing and biparental inbreeding: a mating system analysis in Lymnaea peregra (Gastropoda: Lymnaeidae)
}

\author{
MARIE-AGNÈS COUTELLEC-VRETO*, LUC MADEC \& ANNIE GUILLER $\dagger$ \\ UMR CNRS 6553, Laboratoire de Zoologie et d'Ecophysiologie (UA INRA), Université de Rennes I, Campus de \\ Beaulieu, Av. du G' Leclerc, 35042 Rennes cedex and †UMR CNRS 6553, Laboratoire de Parasitologie \\ pharmaceutique, Université de Rennes I, Av. du Pr. Léon Bernard, 35043 Rennes cedex, France
}

\begin{abstract}
The mating system was analysed in three populations of Lymnaea peregra, under the mixedmating model (MMM) and the effective selfing model (ESM), using progeny array data and allozyme markers. The results revealed variation among populations for the outcrossing rate ( $t_{\mathrm{m}}$ ranged from 0.646 to 0.983 ). This finding modifies the earlier classification of $L$. peregra as a predominantly outcrossing species. The occurrence of biparental inbreeding and population substructure in one of three populations was suggested from positive $\left(t_{\mathrm{m}}-t_{\mathrm{s}}\right)$ under the MMM, covariation of the effective selfing rate with parental fixation index, as well as the great difference between the effective selfing rate of inbred and outbred parents under the ESM. The within-population distribution of the outcrossing rates varied extensively and may involve different patterns of selection and levels of inbreeding depression among the populations studied. Consistently, the estimation of correlated matings showed different levels of the correlation of selfing within progenies in the three populations. Levels of multiple paternity for the outcrossed progeny were positively associated with higher population outcrossing rates, which may reflect the propensity of preferential outcrossers to copulate actively.
\end{abstract}

Keywords: allozymes, freshwater snail, hermaphroditism, inbreeding, mating system, progeny arrray.

\section{Introduction}

The mating system of a population determines the way in which offspring are generated. Because it is both a factor contributing to population structure and a feature under the influence of other forces of evolutionary importance, the estimation of its parameters and their future trajectories remains difficult. In simultaneous hermaphrodite organisms, the population selfing rate can be inferred from its genetic consequence at neutral markers. The progeny array, or the score of genotypes descended from a common parent, constitutes the unit of observation in different models elaborated in this area. The mixed-mating model (MMM; Fyfe \& Bailey, 1951), developed for plant populations because of the variety of systems they exhibit, assumes that, in a population, individuals practise a mixture of selfing and random outcrossing. More-

\footnotetext{
*Correspondence.E-mail:secretariat-zoo-ecophy@univ-rennes1.fr
}

over, the maternal parents used to infer the mating system under this model are supposed to represent a random sample of the populations, i.e. the selfing rate is independent of the maternal genotype. These simplistic assumptions do not allow the measurement of another source of inbreeding, i.e. mating among relatives, which is likely to be important in genetically substructured populations. Consequently, biparental inbreeding can strongly bias downward the estimate of outcrossing rate because of its property of mimicking selfing (Ennos \& Clegg, 1982; Schoen \& Clegg, 1984). However, the estimation of outcrossing rate with multilocus procedures (Ritland \& Jain, 1981) is less biased by biparental inbreeding than single-locus approaches, and the difference between the two methods provides information on biparental inbreeding (Ritland, 1990a). Further insight into nonrandom outcrossing can be obtained under the effective selfing model (Ritland, 1984), which refers to the apparent selfing rate, $E$, that can be a result of actual selfing and mating among relatives. The model gives separate estimates of this rate 
Table 1 Populations and progeny array characteristics

\begin{tabular}{lccl}
\hline Population & $\begin{array}{c}\text { Number of } \\
\text { families }\end{array}$ & $\begin{array}{c}\text { Total } \\
\text { progeny size }\end{array}$ & Allozyme loci \\
\hline Le Drennec & 34 & 327 & Lap-1, Mdh-1, $\alpha$ Gpd-1 \\
Le Boulet & 26 & 274 & Lap-1, $\alpha$ Gpd-1, Aat -2, Pgi-1 \\
Bazouges & 36 & 344 & Lap $-1, \alpha G p d-1$, Aat -2, Pgi-1 \\
\hline
\end{tabular}

for inbred and outbred parents, and allows the parental fixation index to covary with their average $E$. Such covariation, when positive, indicates population substructure (Ritland \& Ganders, 1987), which may be caused by or contribute to biparental inbreeding.

Freshwater hermaphrodite snails have been the subject of a number of studies on population genetic structure and mating system analysis (see Jarne \& Städler, 1995), but the MMM has never been used until a recent study in Ancylus fluviatilis (Städler et al., 1995). In a survey of 16 freshwater species, Lymnaea peregra was classified as predominantly outcrossing (Jarne, 1995; Jarne \& Städler, 1995). The significant level of inbreeding found in some populations of this species, on the basis of Wright's $F$-statistics (Coutellec-Vreto et al., 1994) may result from selfing and also from biparental inbreeding. The latter process may be important in $L$. peregra because of the patchy distribution of individuals along the edges of ponds.

The aim of the present study was to characterize the mating system in three population of $L$. peregra, in terms of population and family outcrossing rates, population subdivision and biparental inbreeding. These three populations were known to exhibit different inbreeding levels, as measured by Wright's $F_{\text {Is. }}$ Progeny array data based on allozymes were used under the MMM and the ESM. Additionally, the estimation of correlated matings, i.e. the correlation of selfing rate and the correlation of paternity within outcrossed progeny, was performed under the 'sibling-pair' model (Ritland, 1989), and provided further information on patterns of mating in these populations.

\section{Materials and methods}

\section{Sampling and electrophoresis}

Adults were collected from three populations of $L$. peregra, in Brittany (north-western France), during the reproductive period (from 2 May 1995 to 7 June 1995). Evidence for reproductive activity was given by the observation of clutches in the three sample sites. In each population, individuals were collected from an area of about $6 \mathrm{~m}^{2}$ along the edge of the pond. These populations had been studied previously for their genetic structure: Le Drennec (near Brest, Brittany, France), Bazouges (near Rennes, Brittany, France; Coutellec-Vreto et al., 1994) and Le Boulet (near Rennes; unpublished). According to genotypic frequencies, the population of Bazouges was more inbred than the one of Le Boulet, whereas in Le Drennec no heterozygote deficiency was observed. This last population was therefore considered to be mating randomly (Coutellec-Vreto et al., 1994). This choice provided the opportunity to compare mating systems of differently structured populations of the same species.

Individuals were immediately isolated to prevent postcapture copulations and brought to the laboratory, where oviposition was scored over 5 days. Clutches laid after this period were not taken into account in order to avoid the artificial selfing of individuals presumably outcrossing in natural conditions, but which did not find a mate before being collected. One or two egg capsules per maternal parent were incubated in order to constitute progeny arrays. The number of families from each population and their outcrossing progeny size (an average of 10 per maternal parent) are presented in Table 1. Using starch and acrylamide gel electrophoresis, maternal parents and their progeny were assessed for 3-4 polymorphic enzyme loci (Table 1). Electrophoretic conditions have been published elsewhere (Coutellec-Vreto et al., 1994).

\section{Analysis}

Maximum likelihood estimates of the mating system parameters were generated with the programs MLTR (version 0.9; K. Ritland, unpublished) and ESR, developed by K. Ritland (Ritland \& Ganders, 1987). Multilocus and average single-locus outcrossing rates at the population level $\left(t_{\mathrm{m}}\right.$ and $\left.t_{\mathrm{s}}\right)$ were obtained under the mixed-mating model. A positive difference between $t_{\mathrm{m}}$ and $t_{\mathrm{s}}$ indicates the occurrence of 
biparental inbreeding (Ritland, 1990a), because the multilocus procedure is more able to detect given outcrossing events than inferences based on single loci. Sperm and ovule gene frequencies were estimated separately at the population level.

To account for within-population variation, $\boldsymbol{t}_{\mathrm{m}}$ estimates were also calculated at the family level, jointly with the gene frequencies $(p)$ of the sperm outcrossing pool. This joint estimation was made to avoid the bias introduced on $t$ by the among-family variation of $p$, when occurring, if $t$ is estimated under the assumption of constant paternal gene frequencies at the population level (Ritland \& Ganders, 1985). Correlation of paternal parentage (the relatedness between different fathers) results from population substructure and leads to variation in the gene frequencies of the sperm pool to which maternal individuals outcross (Ritland \& Ganders, 1985). Moreover, the multilocus allosperm pool can include a second component, i.e. consanguineous mating (relatedness between paternal and maternal parents). Regressing $p$ upon the maternal genotype allows a test for the significance of this component. Following Ritland (1984), $p$ estimates were regressed upon the additive values of maternal genotypes coded as: 1 for $A A, 0.5$ for $A a$ and 0 for a a $(A$ being the more common allele at a diallelic locus). Significant regression reveals that the relatedness between paternal and maternal genotypes arising from population subdivision adds to the effects of self-fertilization.

Heterogeneity of individual $t$ estimates within populations was assessed with a $G$-test (see Sokal \& Rohlf, 1995), using observed family frequencies of the outcrossed and selfed progenies $\left(f_{\mathrm{i}}\right)$ and population-level estimates to generate expected frequencies $\left(f_{\hat{\imath}}\right)$. Using the $\log$ likelihood ratio, $L, G$ was obtained as follows:

$G=2 \Sigma f_{\mathrm{i}} \ln \left(f_{\mathrm{i}} / f_{\mathrm{i}}\right)$.

Two parameters of correlated matings were estimated with MLTR under the 'sibling-pair' model (Ritland, 1989): the correlation of selfing within progeny arrays $\left(r_{\mathrm{s}}\right)$ and the correlation of outcrossed paternity $\left(r_{\mathrm{p}}\right)$. The former coefficient measures the extent of among-family variation in the mating system, a value of 1 resulting from siblings being entirely derived from either selfing or outcrossing, whereas $r_{\mathrm{s}}=0$ suggests homogeneity of the selfing rate among maternal parents. The latter coefficient, $r_{\mathrm{p}}$, is the proportion of full-sibs among outcrossed sibs, and allows an estimation of multiple paternity, the extent that progeny are sired by several fathers (Ritland, 1989).
The effective selfing model was also applied to the progeny array data, because it provides the estimation of an 'effective selfing rate', $E$, also termed 'apparent selfing' or correlation between mates, which may actually be caused by selfing and/or biparental inbreeding. The program ESR (for effective selfing rate) yields separate average single-locus estimates of $E$ for inbred $\left(s_{\mathrm{i}}\right)$ and outbred parents $\left(s_{\mathrm{o}}\right)$ as well as their average $(E)$. This last quantity is allowed to covary with parental gene fixation $(F)$ :

$D=F(1-F)\left(s_{\mathrm{i}}-s_{\mathrm{o}}\right)$.

Inbred parents are those with fixed loci and outbred parents are those with unfixed loci (Ritland \& Ganders, 1987). $D$ reflects the 'inbreeding assortative selfing rate' or the extent that inbred parents effectively self more than outbred parents. Positive $D$ maintains the variation of $F$ among neighbourhoods, and is therefore an indicator of nonself inbreeding.

We compared $F$-values to zero with the $\chi^{2}$ statistic, following:

$F_{\text {IS }}{ }^{2} N(K-1) \approx \chi^{2}$, with $K(K-1) / 2$ d.f.,

where $N$ is the number of maternal parents and $K$ is the number of alleles per locus (Li \& Horvitz, 1953). Because almost all loci were diallelic for a given population, $K$ was taken as 2 . Moreover, confidence intervals at 95 per cent allowed a test for the difference between $F$-values and zero.

For all the estimates, the expectation maximization (EM) procedure was chosen because of its greater stability, although the alternative method (Newton-Raphson) is generally advocated for predominantly outcrossing populations (Ritland, 1986). Variances of the estimates were obtained via bootstrapping, with the family as the unit of resampling for population estimates and individual progeny for family estimates.

\section{Results}

\section{Population-level analysis of the mating system}

Multilocus and average single-locus estimates of the outcrossing rate and their differences are given for each population in Table 2. The estimates of gene frequencies in the sperm and ovule pools are presented in Table $3 . t_{\mathrm{m}}$ values ranged from 0.646 to 0.983 , suggesting intermediate to predominant outcrossing in the set of populations studied. It was found that $t_{\mathrm{s}}$ values were slightly lower than $t_{\mathrm{m}}$ in the three populations, hence positive $\left(t_{\mathrm{m}}-t_{\mathrm{s}}\right)$ differences. However, standard deviation values showed that this difference was not significantly different 
from zero in the population of Le Drennec, and remained weak in the other two populations.

The analysis of data under the ESM (Table 4) gave mean effective selfing rates $(E)$ that were surprisingly less than $\left(1-t_{\mathrm{m}}\right)$ in the three populations. Because $E$ estimates are based on constant gene frequencies in the populations, whereas $t_{\mathrm{m}}$ and $t_{\mathrm{s}}$ were estimated under separate sperm and ovule pool gene frequencies, the observed differences may be partly caused by this discrepancy. However, they were not significant according to the 95 per cent CI of $E$. Considering inbred and outbred parents, strong divergence was found for the apparent selfing rate between them in the population of Bazouges,

Table 2 Population estimates of the outcrossing rate Lymnaea peregra under the mixed mating model

\begin{tabular}{lccc}
\hline Population & $t_{\mathrm{m}}(\mathrm{SD})$ & $t_{\mathrm{s}}(\mathrm{SD})$ & $\left(t_{\mathrm{m}}-t_{\mathrm{s}}\right)(\mathrm{SD})$ \\
\hline Le Drennec & $0.983(0.035)$ & $0.975(0.031)$ & $0.008(0.018)$ \\
Le Boulet & $0.646(0.092)$ & $0.611(0.095)$ & $0.035(0.020)$ \\
Bazouges & $0.713(0.100)$ & $0.659(0.111)$ & $0.054(0.028)$ \\
\hline
\end{tabular}

$t_{\mathrm{m}}$, multilocus outcrossing rate, $t_{\mathrm{s}}$, single-locus outcrossing rate averaged over loci, and their difference. Variance estimates based upon 300 bootstraps (unit of resampling $=$ family within population). whereas in the two others, $s_{\mathrm{i}}$ and $s_{\mathrm{o}}$ did not differ significantly, reflecting the high standard deviation for $s_{\mathrm{i}}$ and the large 95 per cent CI in both populations (Table 4). Similarly, the population of Bazouges differed from the two others in terms of covariation of $E$ with $F$ : the populations of Le Drennec and Le Boulet did not show any covariation, as a consequence of nearly zero $F$-values ( $D$-values not different from zero; Table 4$)$, whereas, in contrast, inbred individuals tended strongly to effectively self more than outbred parents (positive $D ; s_{\mathrm{i}}>s_{\mathrm{o}}$ ). Positive covariation is known to maintain the variation of $F$ among population subdivisions (Ritland \& Ganders, 1985, 1987) and may reflect the occurrence of such a neighbourhood structure and its influence upon the observed level of parental inbreeding in the Bazouges population.

Maternal parents appeared significantly inbred in one of the three populations, i.e. Bazouges $\left(F=0.180 ; \chi^{2}\right.$-test: $\left.P<0.005\right)$.

\section{Within-population variation}

Interindividual heterogeneity of the mating system is suggested by family $t_{\mathrm{m}}$ estimates. These varied significantly in the three populations ( $G$-test, Table 5 ) and their distribution, represented graphically in Fig. 1, was not similar among populations. In Le

Table 3 Separate paternal and maternal gene frequency estimates for Lymnaea peregra

\begin{tabular}{|c|c|c|c|c|c|c|c|}
\hline \multirow[b]{3}{*}{ Locus } & \multirow[b]{3}{*}{ Allele } & \multicolumn{6}{|c|}{ Population } \\
\hline & & \multicolumn{2}{|c|}{ Le Drennec } & \multicolumn{2}{|c|}{ Le Boulet } & \multicolumn{2}{|c|}{ Bazouges } \\
\hline & & $\begin{array}{c}\text { Paternal } \\
\text { frequencies (SD) }\end{array}$ & $\begin{array}{c}\text { Maternal } \\
\text { frequencies (SD) }\end{array}$ & $\begin{array}{c}\text { Paternal } \\
\text { frequencies (SD) }\end{array}$ & $\begin{array}{c}\text { Maternal } \\
\text { frequencies (SD) }\end{array}$ & $\begin{array}{c}\text { Paternal } \\
\text { frequencies (SD) }\end{array}$ & $\begin{array}{c}\text { Maternal } \\
\text { frequencies (SD) }\end{array}$ \\
\hline \multirow[t]{3}{*}{$M d h-1$} & 1 & $0.544(0.037)$ & $0.603(0.046)$ & & - & - & - \\
\hline & 2 & $0.210(0.036)$ & $0.103(0.034)$ & - & - & - & - \\
\hline & 3 & $0.246(0.027)$ & $0.294(0.042)$ & - & - & - & - \\
\hline \multirow[t]{3}{*}{ Lap-1 } & 1 & $0.405(0.041)$ & $0.426(0.051)$ & $0.170(0.053)$ & $0.113(0.039)$ & $0.359(0.052)$ & $0.319(0.056)$ \\
\hline & 2 & $0.595(0.041)$ & $0.574(0.051)$ & $0.028(0.023)$ & $0.019(0.001)$ & - & - \\
\hline & 3 & - & - & $0.802(0.059)$ & $0.868(0.039)$ & $0.641(0.052)$ & $0.681(0.056)$ \\
\hline \multirow[t]{3}{*}{$\alpha G p d-1$} & 1 & - & - & $0.095(0.042)$ & $0.058(0.033)$ & $0.077(0.033)$ & $0.097(0.036)$ \\
\hline & 2 & $0.571(0.042)$ & $0.691(0.042)$ & $0.905(0.042)$ & $0.942(0.033)$ & $0.923(0.033)$ & $0.903(0.036)$ \\
\hline & 3 & $0.429(0.042)$ & $0.309(0.042)$ & - & - & - & - \\
\hline \multirow[t]{2}{*}{ Aat -2} & 1 & - & - & $0.361(0.101)$ & $0.365(0.054)$ & $0.560(0.073)$ & $0.500(0.041)$ \\
\hline & 2 & - & 一 & $0.639(0.101)$ & $0.635(0.054)$ & $0.440(0.073)$ & $0.500(0.041)$ \\
\hline \multirow[t]{2}{*}{ Pgi-1 } & 1 & - & - & $0.760(0.085)$ & $0.558(0.041)$ & $0.564(0.078)$ & $0.431(0.060)$ \\
\hline & 2 & - & - & $0.240(0.085)$ & $0.442(0.041)$ & $0.436(0.078)$ & $0.569(0.060)$ \\
\hline
\end{tabular}

Standard deviations based upon 300 bootstraps (family = unit of resampling). - , either 'locus not used' or 'allele not present in the sample'. 
Table 4 Estimates of the Lymnaea peregra mating system parameters under the ESM

\begin{tabular}{|c|c|c|c|c|c|c|}
\hline \multirow[b]{3}{*}{ Parameters } & \multicolumn{6}{|c|}{ Population } \\
\hline & \multicolumn{2}{|c|}{ Le Drennec } & \multicolumn{2}{|c|}{ Le Boulet } & \multicolumn{2}{|c|}{ Bazouges } \\
\hline & Estimate (SD) & $95 \% \mathrm{CI}$ & Estimate (SD) & $95 \% \mathrm{CI}$ & Estimate (SD) & $95 \% \mathrm{CI}$ \\
\hline$E$ & $0.030(0.037)$ & $(0.001 ; 0.152)$ & $0.313(0.104)$ & $(0.095 ; 0.515)$ & $0.201(0.072)$ & $(0.100 ; 0.359)$ \\
\hline$s_{\mathrm{i}}$ & $0.141(0.470)$ & $(0.001 ; 0.999)$ & $0.212(0.494)$ & $(0.001 ; 0.999)$ & $0.972(0.104)$ & $(0.906 ; 0.999)$ \\
\hline$s_{\mathrm{o}}$ & $0.030(0.035)$ & $(0.001 ; 0.123)$ & $0.313(0.104)$ & $(0.063 ; 0.510)$ & $0.032(0.081)$ & $(0.001 ; 0.184)$ \\
\hline$F$ & $0.001(0.007)$ & $(0.001 ; 0.025)$ & $0.001(0.041)$ & $(0.001 ; 0.136)$ & $0.180(0.047)^{* * *}$ & $(0.085 ; 0.268)$ \\
\hline$D$ & $0.000(0.006)$ & $(0.000 ; 0.023)$ & $0.000(0.027)$ & $(-0.033 ; 0.075)$ & $0.138(0.037)$ & $(0.071 ; 0.184)$ \\
\hline
\end{tabular}

$E$, average effective selfing rate; $s_{\mathrm{i}}$ and $s_{\mathrm{o}}$, effective selfing rates of inbred and outbred parents; $F$, parental inbreeding coefficient; $D$, covariation of parental $F$ with $E: D=F(1-F)\left(s_{i}-s_{\mathrm{o}}\right)$. Standard deviations (in parentheses) and $95 \%$ confidence intervals based upon 280 bootstraps. $F$ compared with zero with a $\chi^{2}$-test (see text).

***Significantly $\neq 0(P<0.005)$.

Drennec, most individuals had outcrossing rates higher than 0.5 and the class $(0.9-1.0)$ was the most important (17 of 34 families). Very few families exhibited low outcrossing rates in this population. In

Table $5 G$-test for within-population variation of the outcrossing rate in Lymnaea peregra

\begin{tabular}{lccl}
\hline Population & $G(2 \ln L)$ & d.f. & \\
\hline Le Drennec & 279.47 & 33 & $*^{* *}(P<0.005)$ \\
Le Boulet & 207.87 & 24 & $*^{* *}(P<0.005)$ \\
Bazouges & 286.47 & 35 & $*^{* *}(P<0.005)$ \\
\hline
\end{tabular}

contrast, in Le Boulet and Bazouges, the number of individuals with low outcrossing rates was higher. Nevertheless, in Le Boulet, all the classes were nearly equally represented, as opposed to a distribution approaching bimodality in Bazouges. Consistency of the correlation of selfing coefficients (Table 6) with these results was not found exactly: higher in Le Drennec, $r_{\mathrm{s}}$ was close to the value of zero in Le Boulet $\left(r_{\mathrm{s}}=0.111\right)$, indicating more homogeneity among maternal selfing rates in the latter population. Yet, according to individual outcrossing rates, we expected the lowest correlation of selfing in Le Drennec. The highest correlation was found in Bazouges, the population in which the tendency of individual outcrossing rates to exhibit bimodality was

Fig. 1 Frequency distribution of individual outcrossing rates in three populations of Lymnaea peregra.

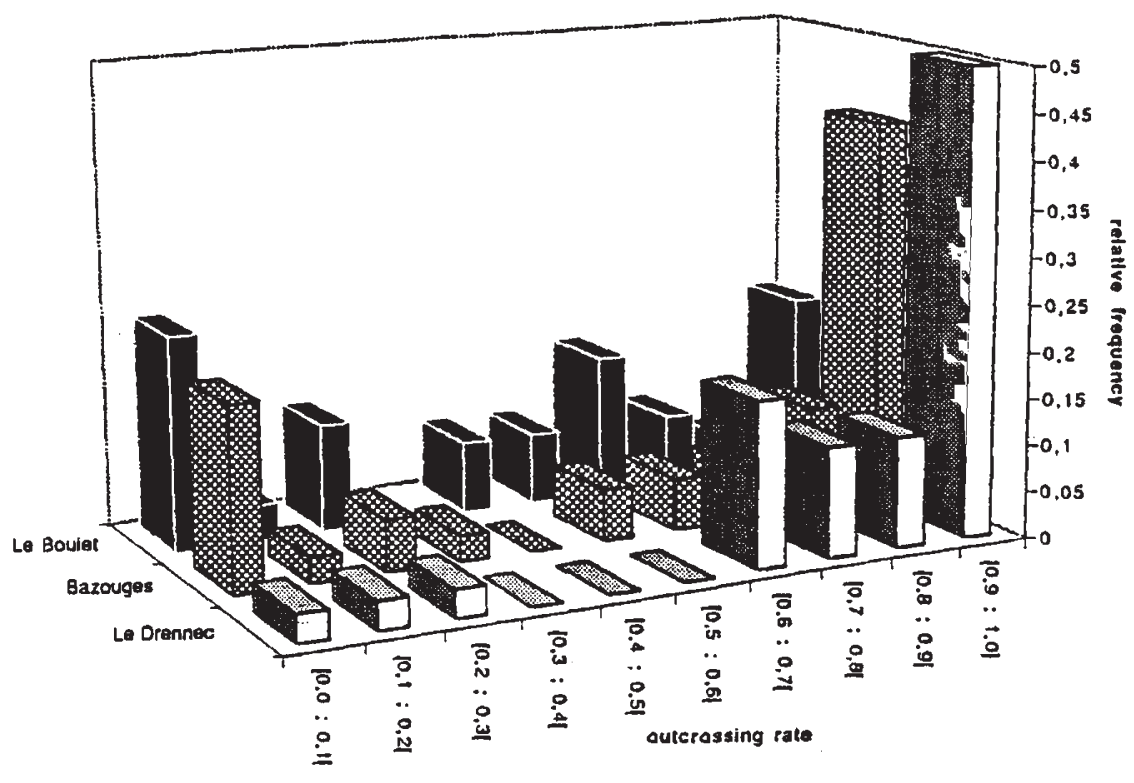

(c) The Genetical Society of Great Britain, Heredity, 79, 277-285. 
Table 6 Correlated mating parameters for Lymnaea peregra under the sibling-pair model

\begin{tabular}{lcc}
\hline Population & $r_{\mathrm{s}}(\mathrm{SD})$ & $r_{\mathrm{p}}(\mathrm{SD})$ \\
\hline Le Drennec & $0.435(0.086)$ & $0.124(0.051)$ \\
Le Boulet & $0.111(0.114)$ & $0.668(0.121)$ \\
Bazouges & $0.788(0.159)$ & $0.412(0.110)$ \\
\hline
\end{tabular}

$r_{\mathrm{s}}$, correlation of selfing within progeny arrays; $r_{\mathrm{p}}$, correlation of paternity within outcrossed progeny. Variance estimates based upon 300 bootstraps (unit of resampling $=$ family within population).

more marked. Thus, in this population, the two approaches were in accord.

Correlation of outcrossed paternity was low in Le Drennec (Table 6), suggesting frequent and successful multiple matings in this population. However, although $r_{p}$ varied substantially among populations, a value of 1 was never reached, therefore excluding the monopaternal origin of outcrossed progeny as a general result.

The gene frequencies of the family outcrossing sperm pool generally did not regress significantly upon the additive values of the maternal genotype, except at the $\alpha G p d-1$ locus in Le Drennec and at the Aat-2 locus in Le Boulet (Table 7). These cases of significance involved negative coefficients and are thus unlikely to be related to consanguineous matings.

\section{Discussion}

The results yielded by the mating system analysis of three populations of $L$. peregra showed heterogeneity both at population and at individual levels. If we trust population estimates, neither selfing nor biparental inbreeding seem to occur in the population of Le Drennec. This would be in accordance with the earlier conclusion, based on adult population structure, that individuals of this population outcross at random. Nevertheless, $t_{\mathrm{m}}$ was not strictly equal to unity, and family estimates revealed some selfing, with a few individuals found to self at rates greater than 70 per cent. Meanwhile, parental inbreeding was zero, suggesting inbreeding depression acting before adulthood, and making selfing events undetectable at this stage, if based on population values of Wright's $F$. Arguing for the selection hypothesis is the strong fitness decrease observed under selfing in this population (M. A. CoutellecVreto et al., unpublished data), because outbred populations are expected to exhibit more inbreeding depression than inbred ones under the partial dominance model (Lande \& Schemske, 1985; Charlesworth \& Charlesworth, 1987). The other two populations showed intermediate and similar outcrossing rates $(0.646$ in Le Boulet and 0.713 in Bazouges) but their mating system differs in other respects. Although biparental inbreeding appeared weak in Bazouges, as suggested by the slight positive difference $\left(t_{\mathrm{m}}-t_{\mathrm{s}}\right)$, its occurrence was confirmed in this population under the ESM by (1) positive covariation of $E$ with $F$; and (2) a great difference between effective selfing in inbred and outbred individuals. In Le Boulet, the same parameter estimates revealed that self-fertilization seems to be the sole source of inbreeding there. Further divergence arose between these populations in means of parental fixation as well as in family outcrossing rates.

In the population of Le Boulet, parental $F$ did not differ significantly from zero, which means that the frequency of homozygotes expected under the observed selfing rate $(s=1-0.646)$ dropped to a value fitting Hardy-Weinberg equilibrium between zygote and adult stages. This may emphasize the occurrence of strong inbreeding depression in this population. In contrast, more inbreeding tolerance is

Table 7 Regression of the gene frequencies of the sperm outcrossing pool upon maternal genotypes for Lymnaea peregra

\begin{tabular}{lccr}
\hline & \multicolumn{3}{c}{ Population } \\
\cline { 2 - 4 } Locus & Le Drennec & Le Boulet & Bazouges \\
\hline Mdh-1 & $-0.004 \mathrm{NS}$ & - & - \\
Lap-1 & $-0.196 \mathrm{NS}$ & $0.051 \mathrm{NS}$ & $-0.131 \mathrm{NS}$ \\
$\alpha$ Gpd-1 & $-0.457^{* *}(P=0.018)$ & $-0.028 \mathrm{NS}$ & $0.113 \mathrm{NS}$ \\
Aat -2 & - & $-0.471^{* * *}(P=0.002)$ & $-0.056 \mathrm{NS}$ \\
Pgi-1 & - & $0.239 \mathrm{NS}$ & $-0.114 \mathrm{NS}$ \\
\hline
\end{tabular}

Significance tested with ANOVA on the regression coefficient. 
suggested in the population of Bazouges by the persistence of the inbreeding level in adults.

Recent models have shown that high inbreeding depression can be maintained with intermediate selfing rates because of selective interference among loci and high mutation rates. The purging effect caused by inbreeding (see Lande \& Schemske, 1985; Charlesworth \& Charlesworth, 1987) cannot occur, unless the selfing rate reaches a threshold value (Lande et al., 1994). Under this hypothesis of inbreeding depression, the selfing rate measured in Le Boulet would lie below the threshold required. Nevertheless, parental fixation does not directly reflect the inbreeding depression, and the present inferences have to be regarded with caution. An estimation of inbreeding depression using changes of inbreeding levels over generations is possible with Ritland's model (1990b) and can be compared with experimental estimates (M. A. Coutellec-Vreto et al., unpublished results).

Another explanation is that, in Le Boulet, adults may have been sampled too early in the reproductive season; however, under this hypothesis, more exclusively selfed progenies, offspring of virgin individuals, should have been observed. Moreover, the observation of clutches in the site allows us to assume that our sampling was made during the reproductive period.

In the population of Bazouges, the co-occurrence of biparental inbreeding and selfing may be involved in the maintenance of significant fixation in adults. When there is more than one type of inbreeding, the cumulative effect in terms of equilibrium heterozygosity and potential for selection is greater than the sum of individual effects (Hedrick, 1985). Thus, the inbreeding level in Bazouges may be driven by a complex combination of these factors.

Special attention was given to the estimation of multiple paternity. Previous studies of paternity performed in freshwater hermaphrodite snails have been based on pigment or allozyme markers (e.g. Cain, 1956; Rollinson et al., 1989; Wethington \& Dillon, 1991; Njiokou et al., 1993) and allowed the distinction between selfing and outcrossing, but some ambiguity remained in the distinction between multiple outcrossings on the one hand and mixed selfing and outcrossing with one mate on the other (Mulvey \& Vrijenhoek, 1981; Rudolph \& Bailey, 1985). The use of progeny arrays under the siblingpair model constitutes an improvement in accuracy and ease, compared with earlier methods. It was recently performed in a highly selfing freshwater snail, Ancylus fluviatilis, showing limited multiple paternity (Städler et al., 1995). Consistent with this finding, our results, although they are conditioned by the loci studied, revealed a positive relationship between lower levels of multiple outcross paternity and higher selfing rates. Multiple matings represent a way of lessening the effect of random genetic drift (Wethington \& Dillon, 1991). However, the studied populations are from a temperate climate and inhabit the edge of ponds that fluctuate annually but where complete droughts remain rare events. Compared with tropical snails, fewer genetic bottlenecks are to be expected (Jarne, 1995). For instance, Brown \& Richardson (1988) failed to find any difference in heterozygosity between populations of the temperate snail, Lymnaea elodes, from vernal and permanent ponds. Alternatively, less intensive copulatory behaviour has been shown to be associated with higher selfing (Jarne et al., 1993) and may well explain the relationship we found between the outcrossing rate and the correlation of paternity.

Although the self-compatibility of $L$. peregra has been demonstrated (Diver et al., 1925) and experimentally studied (Jarne \& Delay, 1990), the occurrence of selfing in natural populations has not yet been ascertained. Moreover, this mating system appears at first sight unlikely to be selected for, given the severe self-fertilization depression observed in two populations of this species (Jarne \& Delay, 1990; M. A. Coutellec-Vreto et al., unpublished observations). A second argument against the natural practice of selfing is the high level of allozyme variation exhibited by $L$. peregra, relative to highly selfing freshwater snails, in which a decrease of this kind of polymorphism is generally observed (Jarne, 1995). However, in L. peregra, the analysis of population genetic structure based on allozyme markers revealed inbreeding within populations, as measured by Wright's $F_{\text {IS }}$, and led us to suspect the contribution of selfing, yet without excluding mating among relatives (Coutellec-Vreto et al., 1994). This uncertainty about the nature of inbreeding should have prevented us from applying the mixed-mating model to $L$. peregra populations, because of its assumption that either selfing or random outcrossing is practised. Nevertheless, the use of single-locus and multilocus $t$ estimates provides a good method of taking biparental inbreeding into account. Both the MMM and ESM were used because, in the absence of inbreeding assortative selfing (no positive $D$ ), the two models are equivalent, and the MMM has the advantage of furnishing estimates with lower variance (Ritland, 1986).

On the basis of population structure, $L$. peregra was considered to be a predominant outcrosser (Jarne \& Städler, 1995), but this is viewed as a 
tendency which does not exclude intraspecific variation (Jarne, 1995). According to the major modes of mating, in which predominant outcrossers display selfing rates $<0.05$ (Brown, 1990), two of the three populations (Le Boulet and Bazouges) have to be considered as exhibiting a mixed-mating system. This interpopulation variation, added to the significant within-population variation of the outcrossing rate, points out the danger of characterizing mating systems at the species level (see Waller, 1986). Furthermore, inferring mating systems from data on genetic structure is advised against, if it is not combined with other methods (Städler et al., 1995). In $L$. peregra, the examination of three populations was sufficient to uncover at least two differing mating structures. If heterogeneity among the populations studied was expected (as based on their previously estimated fixation levels), the present results may actually be indicative of only part of the potentialities of the species.

\section{Acknowledgements}

The technical collaboration of M. C. Martin is gratefully acknowledged. We thank K. Ritland for distributing his programs via ftp. We also thank $\mathrm{T}$. Städler for advice and helpful comments on the manuscript and P. Jarne and F. Viard for a critical reading.

\section{References}

BROWN, A. H. D. 1990. Genetic characterization of plant mating systems. In: Brown, A. H. D., Clegg, M. T., Kahler, A. L. and Weir, B. S. (eds) Plant Population Genetics, Breeding and Genetic Resources, pp. 145-162. Sinauer Associates, Sunderland, MA.

BROWN, K. M. AND RICHARDSON, T. D. 1988. Genetic polymorphism in gastropods: a comparison of methods and habitat scales. Am. Malac. Bull., 6, 9-17.

CAIN, G. L. 1956. Studies on cross-fertilization and selffertilization in Lymnaea stagnalis appressa Say. Biol. Bull., 111, 45-52.

CHARLESWORTH, D. AND CHARLESWORTH, B. 1987. Inbreeding depression and its evolutionary consequences. Ann. Rev. Ecol. Syst., 18, 237-268.

COUTELlec-VReto, M. A., GUiller, A. AND DAGUZan, J. 1994. Allozyme variation in some populations of the freshwater snails Lymnaea peregra, $L$. auricularia and $L$. stagnalis (Gastropoda: Pulmonata). J. Moll. Stud., 60, 393-403.

Diver, C., BOYCOTT, A. E. AND GARSTANG, s. 1925. The inheritance of inverse symmetry in Limnaea peregra. $J$. Genet., 15, 113-200.
ENNOS, R. A. AND CLEGG, M. T. 1982. Effect of population substructuring on estimates of outcrossing rate in plant populations. Heredity, 48, 283-292.

FYFE, J. L. AND BAILEY, N. T. J. 1951. Plant breeding studies in leguminous forage crops. I. Natural crossbreeding in winter beans. J. Agric. Sci., 41, 371-378.

HEDRICK, P. w. 1985. Inbreeding and selection in natural populations. In: Gregorius, H.-R. (ed.) Population Genetics in Forestry, pp. 71-91. Lecture Notes in Biomathematics 60. Springer-Verlag, New York.

JARNE, P. 1995. Mating system, bottlenecks and genetic polymorphism in hermaphrodite animals. Genet. Res., 65, 193-207.

IARNE, P. AND DELAY, B. 1990. Inbreeding depression and self-fertilization in Lymnaea peregra (Gastropoda: Pulmonata). Heredity, 64, 169-175.

JARNE, P. AND STÄDLER, T. 1995. Population genetic structure and mating system evolution in freshwater pulmonates. Experientia, 51, 482-497.

JARNE, P., VIANEY-LIAUD, M. AND DELAY, B. 1993. Selfing and outcrossing in hermaphrodite freshwater gastropods (Basommatophora): where, when and why? Biol. J. Linn. Soc., 49, 99-125.

LANDE, R. AND SCHEMSKE, D. W. 1985. The evolution of self-fertilization and inbreeding depression in plants. I. Genetic models. Evolution, 39, 24-40.

L.ANDE, R., SCHEMSKE, D. W. AND SCHULTZ, S. T. 1994. High inbreeding depression, selective interference among loci, and the threshold selfing rate for purging recessive lethal mutations. Evolution, 48, 965-978.

LI, C. C. AND HORVITZ, D. G. 1953. Some methods of estimating the inbreeding coefficient. Am. J. Hum. Genet., $\mathbf{5}, 107-117$.

MULVEY, M. AND VRIJENHOEK, R. C. 1981. Multiple paternity in the hermaphrodite snail, Biomphalaria obstructa. J. Hered., 72, 308-312.

NJIOKOU, F., BELLEC, C., JARNE, P., FINOT, L. AND DELAY, B. 1993. Mating system analysis using protein electrophoresis in the self-fertile hermaphrodite species Bulinus truncatus (Gastropoda: Planorbidae). J. Moll. Stud., 59, 125-133.

RITLAND, K. 1984. The effective proportion of self-fertilization with consanguineous matings in inbred populations. Genetics, 106, 139-152.

RITLAND, K. 1986. Joint maximum likelihood estimation of genetic and mating structure using open-pollinated progenies. Biometrics, 42, 25-43.

RITLAND, K. 1989. Correlated matings in the partial selfer Mimulus guttatus. Evolution, 43, 848-859.

RITLAND, K. 1990a. A series of FORTRAN computer programs for estimating plant mating systems. J. Hered., 81, 235-237.

RITLAND, K. 1990b. Inferences about inbreeding depression based on changes of the inbreeding coefficient. Evolution, 44, 1230-1241.

RITLAND, K. AND GANDERS, F. R. 1985. Variation in the mating system of Bidens menziesii (Asteraceae) in relation to population substructure. Heredity, 55, 235-244.

(c) The Genetical Society of Great Britain, Heredity, 79, 277-285. 
RITLAND, K. AND GANDERS, F. R. 1987. Covariation of selfing rates with parental gene fixation indices within populations of Mimulus guttatus. Evolution, 41, 760-771.

RITLAND, K. AND JAIN, s. K. 1981. A model for the estimation of outcrossing rate and gene frequencies using $n$ independent loci. Heredity, 47, 35-52.

ROLLINSON, D., KANE, R. A. AND LINES, J. R. L. 1989. An analysis of fertilization in Bulinus cernicus (Gastropoda: Planorbidae). J. Zool., 217, 295-310.

RUDOlPh, P. H. AND BAILEY, J. B. 1985. Copulation as females and use of allosperm in the freshwater snail genus Bulinus (Gastropoda: Planorbidae). J. Moll. Stud., 51, 267-275.
SCHOEN, D. J. AND CLEGG, M. T. 1984. Estimation of mating system parameters when outcrossing events are correlated. Proc. Natl. Acad. Sci. U.S.A., 81, 5258-5262.

SOKAL, R. R. AND ROHLF, F, J. 1995. Biometry, 3rd edn. W. H. Freeman, New York

STÄDLER, T., WEISNER, S. AND STREIT, B. 1995. Outcrossing rates and correlated matings in a predominantly selfing freshwater snail. Proc. R. Soc. B., 262, 119-125.

WALLER, D. M. Is there disruptive selection for self-fertilization? Am. Nat., 128, 421-426.

WETHINGTON, A. R. AND DILLON, R. T., JR 1991. Sperm storage and evidence for multiple insemination in a natural population of the freshwater snail. Physa. Am. Malac. Bull., 9, 99-102. 